ods and computer programs as in 1986 (Thorning \& Hansen, 1987). By October 1987 all profiles were reproduced in hard copy, digitized and processed to migrated ice-thickness data. However, the data have not yet been gridded into maps, as it is the intention to compile a combined data base of EMR data from 1985-1987, and scrutinize this for internal consistency before producing improved maps of ice-thickness; subglacial relief and hydrological potential.

Acknowledgements. We thank Bo Madsen, GTO (cooperation in the field); Ove Karlquist, Greenlandair Charter pilot (flying under difficult conditions); $M$. Svane Jørgensen and Dorthe Nyland Sørensen, GGU, (data processing); Anders Clausen (construction of the new radar antenna). Part of the cost of GTO's navigation system was defrayed by Energiafdelingen, GTO.

\section{References}

Thomsen, H. H., Thorning, L. \& Braithwaite, R. 1986: Vurdering af de gletscher-hydrologiske forhold på Indlandsisen ved Paakitsup Akuliarusersua, Ilulissat/Jakobshavn. Arbejdsnotat. Geol. Surv. Greenland. 82 pp.

Thorning, L., Thomsen, H. H. \& Hansen, E. 1986: Geophysical investigations at the Inland Ice margin of the Pâkitsoq basin, central West Greenland. Rapp. Gronlands geol. Unders. 130, 114-121.

Thorning, L. \& Hansen, E. 1987: Electromagnetic reflection survey 1986 at the Inland Ice margin of the Pâkitsoq basin, central West Greenland. Rapp. Gronlands geol. Unders. 135, 87-95.

\title{
Construction and testing of a lightweight radar for ice-thickness determinations on glaciers in the Pâkitsoq area, central West Greenland
}

\author{
Leif Thorning and Egon Hansen
}

Although the helicopter-borne EMR surveys described in Thorning \& Hansen (1988) resulted in excellent results from most of the catchment area of interest for the hydropower plant planned for Jakobshavn, there are still some local areas, such as the glacier lobes and ice-falls; where no meaningful data could be obtained. In the autumn of 1986 it was decided to construct a monopulse ice radar for use in such areas.

\section{Construction}

The instrument was constructed at GGU using a subcontractor for the high voltage power supply. The principle of the ice radar and good advice on its construction is given in Hodge (1978), which we followed closely. The principle and main components are shown in fig. 1 .

The instrument consists of two separate parts: the transmitter and the receiver.

The transmitter contains a $750 \mathrm{~V}$ DC power supply and a circuit containing four transistors. These are brought to avalanche and pulse with a repetition rate of approximately $6 \mathrm{kHz}$ over a load of $400 \mathrm{ohm}$. The choice of output frequency is then made through the choice of antenna length.

The signal from the receiver antenna is fed into an oscilloscope. The signal on the oscilloscope shows the direct pulse through air (used for triggering the sweep) and the reflected pulse delayed in proportion to the distance travelled through ice (fig. 2). The two-way travel time is calculated as the delay time for the arrival of the reflected pulse read off the oscilloscope plus the travel time for the direct pulse through air. For documentation a photograph is taken of the oscilloscope screen and its setting using a camera with date/time backpanel.

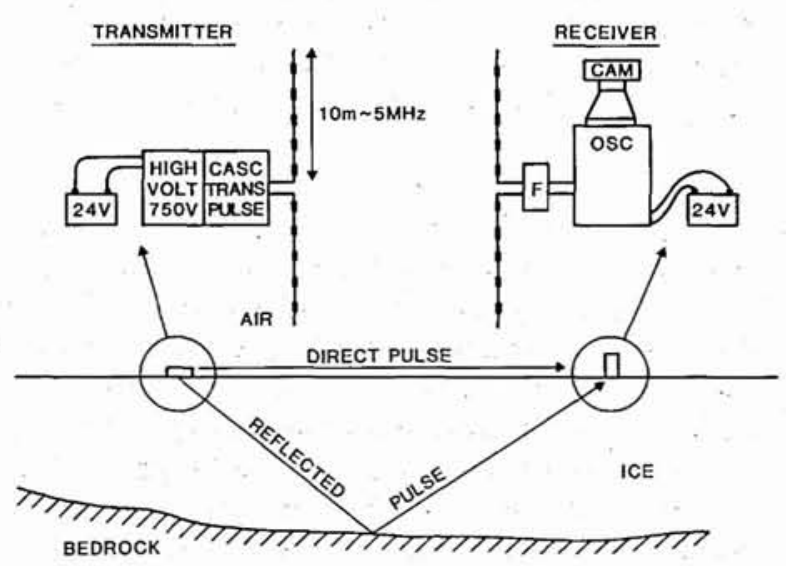

Fig. 1. Principle of the mono-pulse ice radar. For explanation, see text. 
Several sets of antennas were constructed for different frequencies, in half-antenna lengths of $1.25,2.5,5$, 10,20 , and $40 \mathrm{~m}$, corresponding to peak frequencies of $40,20,10.5,2.5$, and $1.25 \mathrm{mHz}$. Each antenna is a resistively-loaded, centre-fed dipole, identical and symmetric about the feed point. The antenna wire with interspersed resistors was enclosed in a plastic tube with test points at the ends to check for continuity. The antennas were flexible and easy to handle even at the low temperatures prevailing on the ice. The power supply was from rechargeable batteries for both transmitter and receiver.

Velocities for radio waves were chosen at $300 \mathrm{~m} / \mu \mathrm{s}$ in air and $168 \mathrm{~m} / \mu \mathrm{s}$ in ice.

\section{Field work 1987}

As part of the glaciological work in the Pâkitsoq area (Thomsen, 1988) and the continuation of the EMR surveys, the last of which took place in April 1987 (Thorning et al., 1986; Thorning \& Hansen, 1987; Thorning \& Hansen 1988), a program was planned for detailed measurements around drill sites and on the glacier lobes to test the instrument and produce useful data for the hydrological work. Besides using the ice radar at different localities and on different types of ice, a series of experiments using different frequencies, different transmitter-receiver distances, profiling and expanding spread around a fixed common midpoint were planned to demonstrate the capabilities and limitations of the equipment on the Greenland Inland Ice. However, as it turned out, much time was wasted on equipment failures manifesting themselves in burned-out components in the high voltage supply circuit. Thus, only a limited part of the program could be carried out. It was, however, enough to demonstrate the usefulness of the ice radar, and to get some ideas on how to improve GGU's version. The work was based at the camp on the Inland Ice shared with the GGU glaciologist working in the area (Thomsen, 1988).

\section{Discussion of results}

Work was carried out in three areas.

In the area adjacent to the first hole drilled through the ice (Olesen \& Clausen, 1988), the ice thickness of approximately $300 \mathrm{~m}$ fitted well with both the results from the EMR surveys and from the logging of the hole. The returned signal was weak, but easily recognizable.

The second area was near a drainage system in a depression in the ice surface where the drilling ran into difficulties, probably due to material of some sort in the ice at approximately $270 \mathrm{~m}$ depth and some $60 \mathrm{~m}$ above

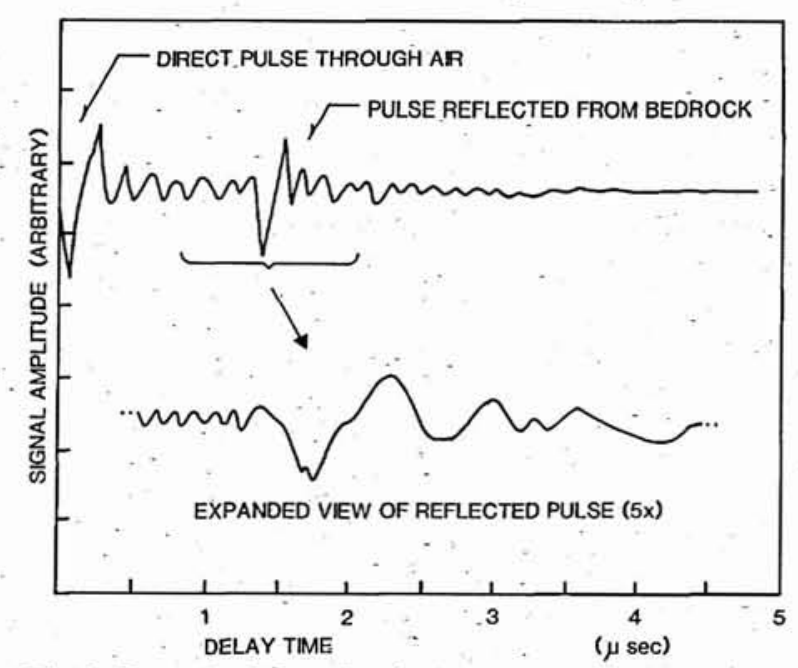

Fig. 2. Example of recording (redrawn from photo).

the bedrock. Here transmitter-receiver (T-R) distance was varied from 50 to $200 \mathrm{~m}$ and all frequencies were tried. Although the direct pulse was always well defined, no reflected pulse could be recognized in the field. Presumably, the material (sand, gravel, rock ?) which gave difficulties for the drilling, also completely scattered the radar waves and diminished the returning signal to below the noise level. This does not mean that it is impossible to obtain data from such an area in the future. The 'contamination' of the ice may vary locally,

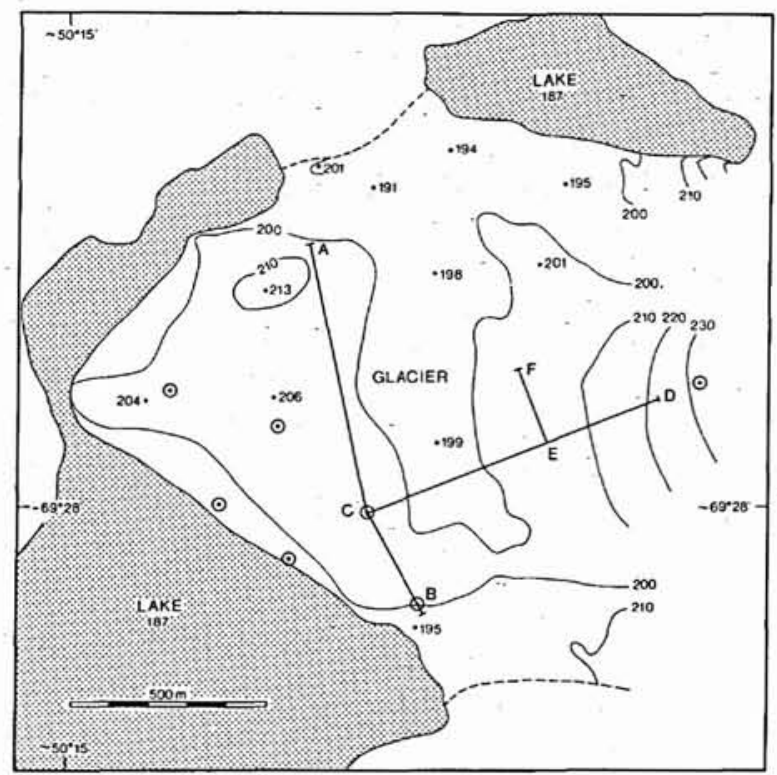

Fig. 3. Position of profiles on the surface of the glacier into lake 187. Transmitter-receiver distance $100 \mathrm{~m}$. The circled points are positions of stakes. Contours and points show elevation of surface. 


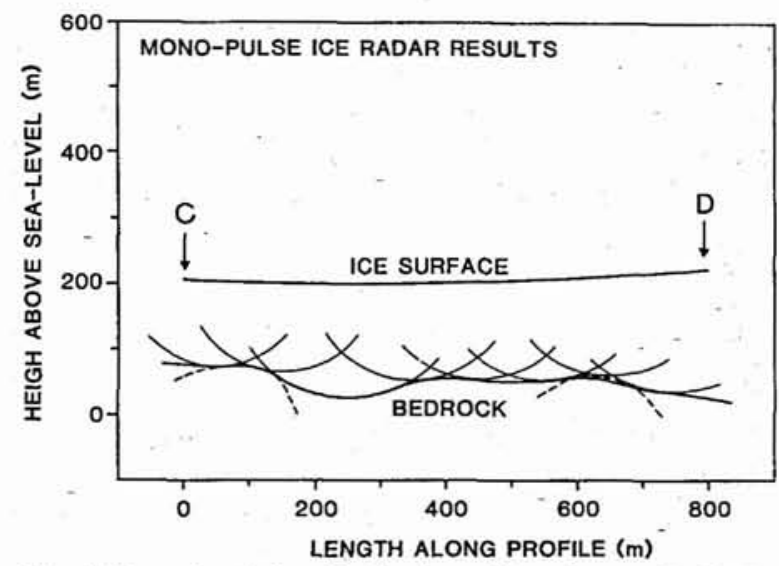

Fig. 4. Example of plot of reflection ellipses for profile $C D$ in fig. 3. The two tops (at 100 and $600 \mathrm{~m}$ ) would be an equally correct interpretation (shown with stippled line).

and it may be a question of moving the equipment around, until a place is found where the signal gets through. Unfortunately, there was no time to do this in 1987.

The third area, the lobe of the glacier into lake 187, yielded the most promising results. Here $2 \mathrm{~km}$ of profiles with a T-R separation of $100 \mathrm{~m}$ gave good, clear return signals at all measuring points. The antenna length was $20 \mathrm{~m}$ corresponding to $5 \mathrm{mHz}$, a frequency often quoted in the literature as suitable for this type of environment. In fig. 3 the position of the profiles on the glacier is shown where point $C$ is at stake 2.1.

The calculated two-way travel time cannot be directly converted into ice thickness, because it cannot be assumed that the return signal comes from below the midpoint. For each position of the transmitter and receiver the reflected signal may come from any point on an ellipsoid with transmitter and receiver in the focal points. A program has been made following Blatter (1987; personnal communication, 1987), which calculates and plots this ellipse in the vertical plane of the profile for each measurement position (fig. 4). If no other information is available, the envelope of these ellipses probably represents the best estimate of the upper limit of the bedrock relief. However, alternative interpretations are possible, as indicated on fig. 4. More detailed measurements using other geometries and sampling intervals may well limit the ambiguity significantly.

Using this simple approach the cross-sections (fig. 5) were constructed giving ice thicknesses of $70-50 \mathrm{~m}$. These represent the first estimates of the ice thickness of this glacier based on direct measurements, but they are not yet sufficiently detailed to determine the character of the bottom of the glacier, i.e. whether it is a
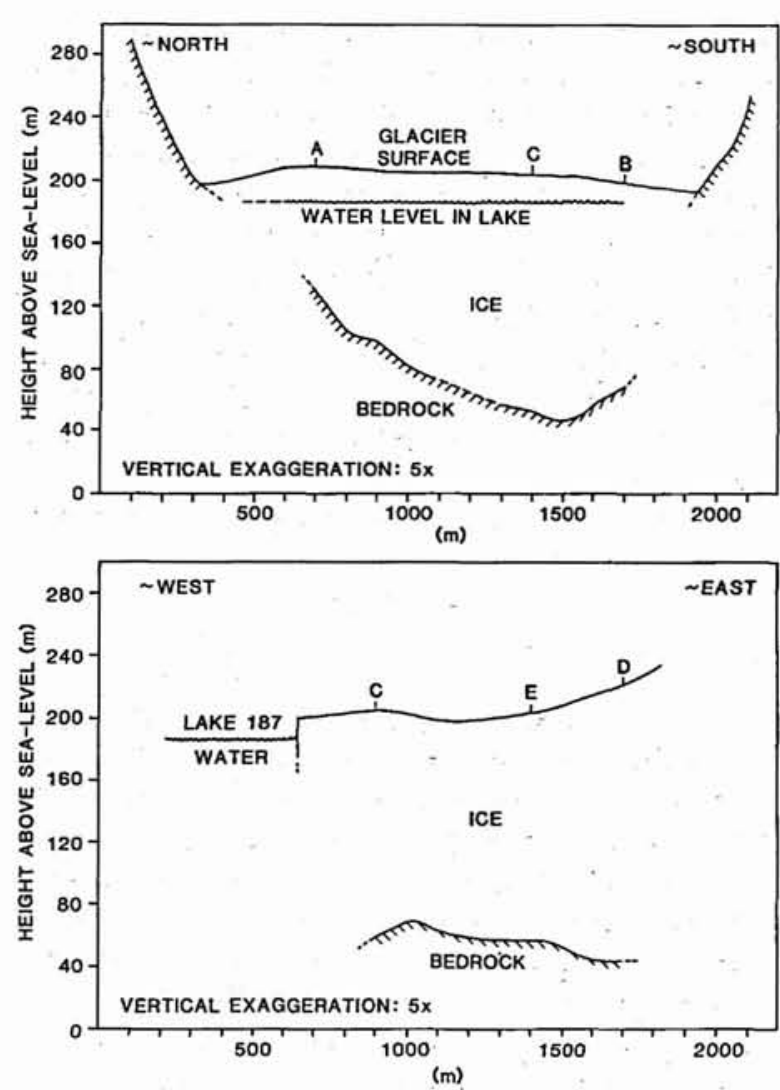

Fig. 5. Sections constructed from the ice radar measurements. Profile positions indicated on fig. 3 .

bedrock/ice or water/ice interface; at present the former possibility is favoured. The results will be added to the EMR data base, and improve map accuracy in this area.

\section{Future work}

Based on the experiences with the monopulse ice radar, technical improvements have been planned. More detailed work will probably be attempted next year on the lobe of the glacier into lake 187, aimed at an accurate mapping of the bedrock/water surface below the glacier. Methods for data reduction will also be refined.

Acknowledgements. We would like to thank other members of the camp on the ice for pleasant cooperation. Lisbeth Christensen, GGU, participated in this work as an assistant.

\section{References}

Blatter, H. 1987: Stagnant ice at the bed of White Glacier, Axel Heiberg-Island, N.W.T., Canada. Ann. Glaciol. 9, 35-38. 
Hodge, S. M. 1978: USGS Mono-pulse ice radar. U.S. geol. Surv. Open File Rep. 9 pp.

Olesen, O. B. \& Clausen, A. 1988: Test drilling with a hot water jet at the Inland Ice margin, Pâkitsup, central West Greenland. Rapp. Grønlands geol. Unders. 140.

Thomsen, H. H. 1988: Mapping and modelling of glacier drainage in the. Pâkitsoq basin, central West Greenland. Rapp. Grønlands geol. Unders. 140.

Thorning, L., Thomsen, H. H. \& Hansen, E. 1986: Geophysical investigations over the Inland Ice margin of the Pâkitsoq basin, central West Greenland. Rapp. Grønlands geol. Unders. 130, 114-121.

Thorning, L. \& Hansen, E. 1987: Electromagnetic reflection survey 1986 at the Inland Ice margin of the Pâkitsoq basin, central West Greenland. Rapp. Grønlands geol. Unders. 135, 87-95.

Thorning, L. \& Hansen, E. 1988: Electromagnetic reflection survey 1987 in key areas of the Pâkitsoq basin at the margin of the Inland Ice, central West Greenland. Rapp. Grønlands geol. Unders. 140.

\title{
Test drilling with a hot water jet at the Inland Ice margin, Pâkitsup, central West Greenland
}

\author{
Ole B. Olesen and Anders Clausen
}

A new hot water jet drill was tested on the Inland Ice margin north-east of Jakobshavn. A total of $2436 \mathrm{~m}$ was drilled and data on drilling performance is presented together with the preliminary interpretation of borehole logging.

\section{Introduction}

One of the main problems in assessing potential water sources for hydroelectric power plants using meltwater from the Inland Ice is the delineation of the drainage basin. In the case of the proposed project at Paakitsup Akuliarusersua this delineation has been attempted by a combination of surface topography and drainage systems, radio-echo soundings, mass balance measurements, ice dynamics and present theories on the internal drainage of glaciers (summarized by Thomsen et al., 1986).

The subglacial or englacial drainage of glaciers, particularly where temperatures are below the pressure melting point is not very well understood. From both practical and scientific considerations it therefore seemed reasonable for GGU to start research using the basin at Paakitsup Akuliarusersua as a test area. Among important aspects of this research are the monitoring of hydrostatic pressure variations within the drainage system, tracer experiments and subglacial and surface topographic mapping. This requires the installation of gauges at different levels in the ice, the injection of tracers and withdrawal of water from specified locations and spot checks on the accuracy of the radio-echo soundings made in the area. The only practical way of accomplishing this programme is by drilling, and it was therefore decided that GGU should either buy or develop its own drill.

\section{Equipment}

As no ice-core samples were required and a regular borehole diameter was unimportant, it was decided to use a hot water jet to penetrate the ice. This type of drilling is the fastest and most reliable method and has been widely used in the Alps (Iken et al., 1977). We had an opportunity to examine the Swiss system at the Swiss Federal Institute of Technology (ETH) in Zürich and used it as a basis for our own drill.

The basic principle consists of pumping water through a heating system and into a hose with a rigid drill tip with a nozzle. The hot water from the nozzle melts the ice in front of it and flows back up the drill hole. All the main elements in the system are commercially available, but the actual fitting and mounting of the different components is unique to this system. The central part of the drill consist of two units, a power unit and a heating unit (fig. 1). The power unit is a $6 \mathrm{~kW}$ four stroke gasoline engine with reduction gear connected with an $0.4 \mathrm{~kW} 220 \mathrm{~V}$ generator and a piston pump capable of delivering $18 \mathrm{l} / \mathrm{min}$. of water with a pressure of up to 100 bar. Fuel consumption is $2.5 \mathrm{l} / \mathrm{hr}$ and the total weight of this unit is $79 \mathrm{~kg}$. The heating unit is a water circulation coil with an oil burner (modified for using jet A1 fuel). The airblower and oil pump are driven by a flexible axle from the power unit, and current for the ignition is drawn from the generator. Fuel consumption is $11.6 \mathrm{l} / \mathrm{hr}$ corresponding to $113 \mathrm{~kW}$ and the weight is $127 \mathrm{~kg}$. During drilling the two units can be used separately (to 